\section{The Human Blood Proteins}

Prof. F. WuhrmanN, M.D.; C. Wunderly, PH.D. Translated from the third edition by $\mathbf{H}$. 'T. Adelson, M.D. Pp. xi $+49 \mathrm{I}$, illustrated. New York and London: Grune \& Stratton. 1960. $\$ 15.75$.

This book will be of interest to physicians and pathologists who require an up-to-date monograph on the plasma proteins. The author's treatment of physical and chemical topics is suitable for non-specialists in these fields.

Chapter I contains an adequate account of the chemistry of the plasma proteins. This section could, of course, have been expanded, but to have done so would have upset the balance of the book. Study of this chapter would be a good introduction to the more detailed original literature. The chemical methods of determining proteins are described in Chapter II.

Chapter III-' Methods of Examination '-describes the procedures such as salting-in, salting-out, precipitation by various combinations of organic solvents at low concentration and electrolytes ( $c f$. the studies of $\mathbf{E}$. J. Cohn and his colleagues), electrophoresis (in free solution and on supporting media), immunoelectrophoresis and ultracentrifugation, which have provided so much of the present body of knowledge concerning the plasma proteins. Chapter IV, 'Clinical Chemical Methods', and Chapter V, 'Clinical Significance of the Plasma Proteins', deal with the practical details and the interpretation of the results of the various 'empirical' tests which depend upon changes in the composition and stability of the plasma proteins. The reviewer was left with the impression that more attention is paid to these tests in the author's departments than is usually done in Great Britain. Chapter VI, 'Clinical Significance of the Dysproteinæmias and Paraproteinæmias', reduplicates some of the material given in the earlier chapters but is, in the present writer's opinion, the best in the book.

This work is both comprehensive and authoritative, and the numerous references to the continental, as well as to the British and American literature should commend it to those readers who lack the time and/or the linguistic ability to study the medical literature of continental Europe in the original. It can be recommended to postgraduate medical students as a work of reference.

\section{Artefacts and Handling and Processing Faults on X-ray Films}

Prof. Dr. E. A. Zimmer. Pp. 67, with 128 illustrations. New York and London: Grune \& Stratton. 1960. \$5.75.

Film faults and artefacts are not infrequently met with on X-ray films and their interpretation by an inexperienced operator may be very difficult. This book consists mainly of illustrations of the various types of film faults, which are grouped in accordance with their appearance on each film.

The cause of each film fault is briefly explained and hints given on how to avoid it, or if possible how to improve the existing picture by simple methods.

The illustrations are of high quality and are reproduced in the negative, i.e. they appear in the same way as normally viewed $\mathrm{X}$-ray plates.

The book is well recommended to all who carry out processing and interpretation of $\mathrm{X}$-ray films.

\section{Epilepsy and Related Disorders}

William GoRdon LenNox, A.B., A.M., M.D., ? SC.D.(HON.), with the collaboration of MARGARET A. \ LENNOX, A.B., M.D. Pp. xxv + xx + 1,168, 203 른 figures, 2 volumes. London: J. \& A. Churchill. I 960 . $96 s$.

This is in every sense an individual book. It was written by the late Dr. William G. Lennox, an individual who devoted the major part of his life to the study and care of patients with epilepsy. He saw the individual with the disease, rather than a disease process occurring in vacuo, and these two volumes contain the fruits of his long experience in this field.

The work is set in a true historical perspective by the interesting account of the story of epilepsy from earliest times, amply illustrated by carefully chosen prints. The nature of epilepsy is assessed in relation to the occurrence of other periodic or recurrent phenomena in biology, and the author then goes on to describe and classify the various types of seizure which may be encountered in this condition of many facets. It is in this section that the work is at its best, for we have here the experience of a doctor who had been observing seizures, with interest and understanding, for the greater part of his lifetime. The individual case histories are of special value, being so well chosen to give practical illustration to specific points. But the evidence is not only anecdotal for the indispensable electroencephalogram, and the statistical and genetic backgrounds of the subject are fully discussed.

The treatment section again shows the mark of a physician interested in patients with a disease rather than the disease itself. Thus not only is the use of drugs and surgery fully discussed, but the all-important socialo emotional and marital problems are handled with the sureness of one writing from practical experience in the clinic. An interesting chapter on famous people who have suffered from epilepsy adds to this section, and an extensive bibliography completes the book.

This is not the kind of book one sits down to read from cover to cover. But to anyone interested in the problems of epilepsy, it is indispensable, for they will never open its pages without finding some snippet of information and experience which will be of value to them in their care of patients.

\section{Chromatographic and Electrophoretic Techniques}

Editor: IvoR SMITH, B.SC., PH.D., F.R.I.C. London Wm. Heinemann Medical Books. I960. Vol. I £3 5s.; Vol. II, £I ros.

The first edition of this book was published only two years ago, as a slim volume of 309 pages contributed by ten authors. This second edition is in two volumes, totalling 832 pages contributed by 29 authors; yet only about 50 pages deal with matters which are not of direct clinical or pharmacological importance.

The increase reflects the tremendous increase in knowledge of metabolic processes which has been obtained with the aid of chromatography and of zone electrophoresis. This book contains no padding, nor is it an exhaustive treatise; it is a laboratory workers' exposition of the most important techniques and advances in knowledge made by using them. The editor, Dr. I. Smith, has been eminent among those who have applied these techniques to clinical matters, and has designed equipment and modified techniques with the deliberate purpose of making the analyses simple and rapid. His routine methods are widely known from his teaching at the Brunel Technical .

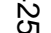

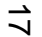
$\vec{\theta}$ . . 